\title{
ALIGNING THE BRUSSELS REGIME WITH THE REPRESENTATIVE ACTIONS DIRECTIVE
}

\author{
FREDERICK RIELAENDER*
}

\begin{abstract}
European private international law has long been recognised as improperly set up to deal with cross-border collective redress. In light of this shortcoming, it seems unfortunate that the private international law implications of the Representative Actions Directive (Directive (EU) No 2020/1828) have not yet been addressed coherently by the European legislator. This article examines to what extent the policy of promoting collective redress can be supported, even if only partially, through a reinterpretation of the jurisdictional rules of the Brussels Ia Regulation. Furthermore, it discusses which legislative measures need to be adopted to better accommodate collective redress mechanisms within the Brussels regime.
\end{abstract}

Keywords: jurisdiction, parallel proceedings, choice-of-court agreements, European private international law, Brussels Ia Regulation, collective redress, representative actions, Directive (EU) No 2020/1828.

\section{INTRODUCTION}

While the aim of providing effective means of collective redress ${ }^{1}$ for citizens across the EU has long been on the agenda of EU political institutions, especially the Commission, ${ }^{2}$ the Volkswagen diesel scandal ('Dieselgate')

* Interim Professor, Chair of Civil Law and Private Media Law, European University Viadrina Frankfurt (Oder), frederick.rielaender@uni-osnabrueck.de. I am greatly indebted to Professor Christian von Bar, FBA, MAE, who supervised both my PhD thesis and my Habilitation thesis, for his continued mentorship and invaluable support of all my academic projects in comparative law and private international law. I wish also to thank two anonymous peer reviewers for their valuable comments and the journal for wonderful editorial support. All mistakes remain my own.

${ }^{1}$ The European Commission has continuously employed all-encompassing terminology reflecting the wide variety of national collective redress proceedings in the EU. According to para II.3.a of the Recommendation of 11 June 2013 on common principles for injunctive and compensatory collective redress mechanisms in the Member States concerning violations of rights granted under Union Law [2013] OJ L201/60-5, 'collective redress' is (i) a legal mechanism that ensures a possibility to claim cessation of illegal behaviour collectively by two or more natural or legal persons or by an entity entitled to bring a representative action (injunctive collective redress); (ii) a legal mechanism that ensures a possibility to claim compensation collectively by two or more natural or legal persons claiming to have been harmed in a mass harm situation or by an entity entitled to bring a representative action (compensatory collective redress).

2 See A Pato, Jurisdiction and Cross-Border Collective Redress (Hart 2019) 84-94. 
gave an important impetus to the development of a more incisive policy for strengthening consumer collective redress, ${ }^{3}$ which, ultimately led to the adoption of the new Representative Actions Directive (the 'Directive'). ${ }^{4}$ In light of the highly divergent approaches adopted by the Member States in this politically sensitive domain, ${ }^{5}$ the new Directive, broadly in line with the Commission's proposal from $2018^{6}$, provides for a minimal harmonisation of consumer collective redress.

In brief, the Directive requires Member States to adopt at least one efficient collective action mechanism that enables consumer associations and other qualified entities (QEs) to bring representative actions seeking injunctive measures (Article 8) and/or redress measures (Article 9) against traders with respect to infringements of EU law in a broad range of matters, including, inter alia, product liability and product safety, data protection, travel and tourism, financial services, energy, telecommunications and health (Articles 1 and 2(1), Recitals 7, 8 and 13). On the whole, the Directive takes a cautious approach, as reflected in its various safeguards aimed at preventing vexatious litigation, such as the stringent requirements entities must comply with in order to be eligible to bring 'cross-border representative actions' (Article 4) and the rules on the funding of representative actions for redress measures (Article 10). ${ }^{7}$

\footnotetext{
3 A Biard and XE Kramer, 'The EU Directive on Representative Actions for Consumers: A Milestone or Another Missed Opportunity?' (2019) 27(2) ZEuP 249.

${ }^{4}$ Directive (EU) No 2020/1828 of the European Parliament and of the Council of 25 November 2020 on representative actions for the protection of the collective interests of consumers and repealing Directive 2009/22/EC [2020] OJ L409/1.

${ }^{5}$ See R Amaro et al., Collective Redress in the Member States of the European Union European Parliament 2018, 17-43<http://www.europarl.europa.eu/RegData/etudes/STUD/2018/608829/ IPOL_STU(2018)608829_EN.pdf>. While a number of Member States have yet to adopt compensatory collective redress tools, others, most notably the Netherlands, have taken a more incisive approach towards collective redress. In this context, the Dutch WCAM procedure (Wet Collectieve Afwikkeling Massaschade), according to which out-of-court settlements concluded between a foundation established by the putative victims of a mass tort and the responsible wrongdoer can be declared binding by the Amsterdam Court of Appeal on all victims referred to in the settlement, including foreign victims, raises several unresolved issues regarding jurisdiction and recognition of approved settlements (see XE Kramer, 'Securities Collective Action and Private International Law Issues in Dutch WCAM Settlements: Global Aspirations and Regional Boundaries' (2014) 27(2) University of the Pacific McGeorge School of Law Global Business \& Development Law Journal 235, 248-71; T Bosters, Collective Redress and Private International Law (Springer 2017) 119-41, 199-211.

${ }^{6}$ Commission, 'Proposal for a Directive of the European Parliament and of the Council on representative actions for the protection of the collective interests of consumers, and repealing Directive 2009/22/EC' COM(2018) 184 final; for a critical appraisal, see Biard and Kramer (n 3) $249-59$.

${ }^{7}$ Essentially, only non-profit organisations with a record of protecting consumer interests may be designated for the purpose of bringing 'cross-border representative actions'. Furthermore, the Directive seeks to prevent abusive litigation by adopting the loser-pays principle (art 12), excluding the awarding of punitive damages (rec 42), and providing that manifestly unfounded representative actions may be summarily dismissed (art 7(7)).
} 
Whether the Directive will meet its objectives, namely, enhancing consumers' access to justice, boosting consumer confidence and contributing to fairer competition in the internal market (Article 1(1), Recital 7), remains to be seen, particularly in light of the fact that the EU legislator did not seise the opportunity to coherently address the difficulties and challenges of crossborder collective redress under the existing European private international law framework. ${ }^{8}$ Admittedly, the Directive makes some slight efforts towards facilitating transnational consumer collective redress by ensuring mutual recognition of legal standing of QEs (Article 6(3)) as well as promoting cooperation and the exchange of information between QEs in order to take action against cross-border infringements (Articles 6(2), 14(3)(b) and 20(4)), while at the same time seeking to protect consumers domiciled in Member States other than the forum State against any unwelcome assertion of their individual rights by a mandatory opt-in mechanism (Article 9(3)). However, the much-discussed shortcomings of the Brussels Ia Regulation ('Brussels Ia'), ${ }^{9}$ above all its tendency to promote parallel proceedings arising from cross-border infringements of EU law, ${ }^{10}$ have not been addressed at all.

In fact, the Directive states that it neither affects the existing private international law rules on jurisdiction, choice of law and the recognition and enforcement of judgments nor establishes such rules (Article 2(3), Recital 21). This legislative self-restraint did not come as a surprise given that the ongoing and highly contentious debate in legal doctrine has made it clear that a general consensus on the best approach to reforming the law for the purpose of improving the efficiency and effectiveness of cross-border collective redress is still a long way off. To be sure, there are no easy solutions in sight. ${ }^{11}$ In this context, consideration must be given to the following competing (and partially conflicting) policy objectives.

First, with regard to mass torts causing considerable individual damages, there is an undisputed need to avoid the threat of inherently inefficient parallel and serial litigation with all its well-known mischiefs: excessive

${ }^{8}$ On this, see, inter alia, Amaro et al. (n 5) 93-113; M Danov, 'The Brussels I Regulation: Cross-Border Collective Redress Proceedings and Judgments' (2010) 6(2) JPrivIntL 359, 364-93; ZS Tang, 'Consumer Collective Redress in European Private International Law' (2011) 7(1) JPrivIntL 101, 106-47; DPL Tzakas, 'Effective Collective Redress in Antitrust and Consumer Protection Matters: A Panacea or a Chimera?' (2011) 48(4) CMLRev 1125, 1153-74.

9 Regulation (EU) No 1215/2012 of the European Parliament and of the Council of 12 December 2012 on jurisdiction and the recognition and enforcement of judgments in civil and commercial matters [2012] OJ L351/1.

${ }^{10}$ B Hess, 'Collective Redress and the Jurisdictional Model of the Brussels I Regulation' in A Nuyts and N Hatzimihail (eds), Cross-Border Class Actions: The European Way (Sellier 2014) 67; Kramer (n 5) 277; E Lein, 'Cross-Border Collective Redress and Jurisdiction under Brussels I: A Mismatch' in D Fairgrieve and E Lein (eds), Extraterritoriality and Collective Redress (Oxford University Press 2012) 141-2, paras 8.33-8.34; C Peraro, 'Cross-border Collective Redress and the Jurisdictional Regime: Horizontal vs Sectoral Approach' in B Hess and K Lenaerts (eds), The 50th Anniversary of the European Law of Civil Procedure (Nomos 2020) 317, 335-7, 343, 348.

11 See HP Mansel, K Thorn and R Wagner, 'Europäisches Kollisionsrecht 2020: EU im Krisenmodus!' (2021) 41(2) IPRax 105, 113. 
strain on judicial resources, additional costs for all parties involved, and irreconcilable judgments. ${ }^{12}$ Second, to improve the efficiency of the regulatory function of EU consumer law and tort law, it is necessary to overcome the 'rational apathy' of consumers when, as is frequently the case, the individual harm suffered by illegal business practices is trivial. ${ }^{13}$ To both of these ends, it is imperative to facilitate the bundling of claims of dispersed consumers or victims in a single court that is easily accessible for the claimant, be it the individuals affected by those practices or a legal person acting on their behalf.

At the same time, a possible reform of Brussels Ia, with a view to promoting collective redress, must work from the principles on which the jurisdictional framework is said to rest: legal certainty, transparency and predictability of jurisdiction, and the sound administration of justice. ${ }^{14}$ In particular, given that substantial differences among the Member States in the area of collective redress are likely to continue to exist, ${ }^{15}$ it is of utmost importance to ensure a high degree of foreseeability of judicial competence and to implement safeguards against forum shopping.

In light of the above, this article offers a fresh account of the deficiencies of the existing jurisdictional rules and a concise evaluation of the various ways of reforming the Brussels regime to better accommodate cross-border collective redress. The article consists of four sections. First, it argues that, contrary to suggestions by other scholars, ${ }^{16}$ the shortcomings of the status quo in the area of jurisdiction cannot, in fact, be resolved by creating novel grounds of derived jurisdiction for the purpose of easing a bundling of similar claims via a reinterpretation of the special grounds of jurisdiction set out in Title II of Brussels Ia. Second, this article explores how parallel mass proceedings could and should be dealt with on the basis of the existing rules governing lis pendens and related actions to avoid inconsistent judgments. Third, it critically engages with several academic proposals aimed at reforming Brussels Ia for the purpose of facilitating cross-border collective redress.

12 See only Amaro et al. (n 5) 108-9.

13 See, in more detail, Tzakas (n 8) 1133-4.

14 See eg Case C-30/20 Volvo EU:C:2021:604, para 38.

15 See Biard and Kramer (n 3) 251. It should be noted that, under Directive (EU) No 2020/1828 (n 4), the Member States enjoy wide discretion regarding the procedural conditions of representative actions (see recs 11, 12, 19 and 43), especially whether the procedure will be judicial or administrative; whether representative actions for redress measures, such as compensation, price reduction, or reimbursement of the price paid (art 3(1) and 9(1)), are based on an opt-in or optout mechanism (art 9(2); and what degree of similarity between claims pursued by a representative action for redress measures is required. Furthermore, the rules regarding the admissibility of evidence and the possibilities of appeal fall within the domain of national law. However, most importantly, Member States are allowed to retain or adopt complementary national collective redress mechanisms (art 1(2)).

16 A Nuyts, 'The Consolidation of Collective Claims Under Brussels I' in A Nuyts and N Hatzimihail (eds), Cross-Border Class Actions: The European Way (Sellier 2014) 69, 77-9; similarly A Halfmeier and P Rott, 'Verbandsklage mit Zähnen? - Zum Vorschlag einer Richtlinie über Verbandsklagen zum Schutz der Kollektivinteressen der Verbraucher' (2018) Verbraucher und Recht (VuR) 243, 250; P Röthemeyer, 'Die neue Verbandsklagen-Richtlinie' (2021) VuR 43, 47. 
This article contends that, contrary to a widely shared view, ${ }^{17}$ it is neither necessary nor even advisable to centralise jurisdiction for collective redress proceedings in a single court by means of implementing a special new ground of jurisdiction in a revised Regulation ('Brussels Ib'). Having rejected the introduction of a 'one-stop-shop jurisdiction', this article develops an alternative approach to promote collective redress that better complies with the principles of the existing European private international law framework. To this end, it calls for a comprehensive overhaul of Brussels $\mathrm{Ia}^{18}$ that should include, inter alia, (i) extending the special grounds of jurisdiction to domiciliaries from third States, (ii) establishing rules that enable a cooperative consolidation of overlapping mass proceedings on a case-by-case basis, and (iii) specifically providing for mutual recognition of court-approved settlements within the EU.

\section{ANALYSIS OF THE STATUS QUO IN THE AREA OF JURISDICTION}

The common belief that Brussels Ia effectively allowed cross-border collective actions to be brought only in the court of the defendant's domicile and, to a much lesser extent, in the court of the place where the harmful event occurred ${ }^{19}$ is difficult to challenge. While the Regulation seeks to counterbalance the strategic advantage granted to the defendant under the fundamental rule of actor sequitur forum rei (Article 4(1), Recital 15 Brussels Ia) by certain special jurisdictional rules, ${ }^{20}$ these special grounds of jurisdiction do not lend themselves to aggregating a multitude of claims of dispersed victims or consumers. As has often been emphasised, Brussels Ia is built on the traditional concept of two-party proceedings, ${ }^{21}$ a tenet embodied in the case law of the European Court of Justice (ECJ), pursuant to which, where multiple claims are accumulated in a single action, jurisdiction needs to be determined independently and separately for each claimant and each claim. ${ }^{22}$ Focusing on the potentially relevant special heads of jurisdiction of Articles 7(1), (2) and 18(1) Brussels Ia, this section confirms and underlines that, despite suggestions by other commentators in the wake of the adoption of Directive (EU) No 2020/ $1828,{ }^{23}$ there is hardly any scope for facilitating the aggregation of multiple claims arising from the same illegal business practice in a single and 'neutral' forum via a reinterpretation of the existing rules.

17 See eg Amaro et al. (n 5) 110; Lein, 'Cross-Border Collective Redress and Jurisdiction under Brussels I: A Mismatch' (n 10) 142, paras 8.36-8.37.

18 The Commission's report on the application of the Regulation, accompanied by a proposal for its amendment, is due on 11 January 2022; see art 79 Brussels Ia.

${ }^{19}$ Lein, 'Cross-Border Collective Redress and Jurisdiction under Brussels I: A Mismatch' (n 10) 141, para 8.33; Pato (n 2) 161, 205-6, 213-15.

${ }^{20}$ See only E Lein, 'Special Jurisdiction for Particular Kinds of Claims' in A Dickinson and E Lein (eds), The Brussels I Regulation Recast (Oxford University Press 2015) 133-4, para 4.07.

${ }^{21}$ Kramer (n 5) 277; Lein, 'Cross-Border Collective Redress and Jurisdiction under Brussels I: A Mismatch' (n 10) 132, para 8.06.

${ }^{22}$ Cases C-147/12 ÖFAB EU:C:2013:490, para 58; C-352/13 CDC Hydrogen Peroxide SA EU:

C:2015:335, paras 35-36; C-498/16 Schrems EU:C:2018:37, para 48.

23 See the references above, at (n 16). 
In this respect, it should, however, first be noted that both 'domestic representative actions' and 'cross-border representative actions' within the meaning of Article 3(6), (7) of the Directive fall within the material scope of Brussels Ia, provided that the action relates to a 'civil matter' (Article 1(1) Brussels Ia), the defendant is domiciled in a Member State (Article 4(1) Brussels Ia) and the dispute exhibits 'international character'. ${ }^{24}$ The misleading terminology used in Article 3(6), (7) in conjunction with Recital 23 of the Directive, according to which a representative action qualifies as a cross-border representative action only if it is brought by a QE established in a Member State other than the forum State, regardless of where the trader and the consumers represented by the action are domiciled, does not suggest a different analysis but must be seen in light of the fact that the EU legislator, as stated, confined itself to regulating the mutual recognition of locus standi of QEs, without tackling the jurisdictional aspects of cross-border collective redress - in the true sense of that term.

\section{A. Aggregating Noncontractual Claims in the Courts of the Place Where the Harmful Event Occurred}

Regarding actions aimed at determining and stopping illegal commercial activities, such as an action concerning the prohibition on traders using unfair terms in contracts concluded with consumers, it can be safely inferred from Henkel $^{25}$ that jurisdiction, as the 'place where the damage occurred' under the second prong of the Bier paradigm, ${ }^{26}$ lies with the courts of the Member State or the Member States in whose territories the general interest of consumers is affected. ${ }^{27}$ While this enables consumer associations to bring cessation actions for the purpose of protecting the general interest of national consumers in the Member States in which the respective entity is established, ${ }^{28}$ entities face much greater difficulties when trying to bring

\footnotetext{
24 As is clear from the ECJ's case law, for the international character of the case to be established, it is not required that the parties to the dispute be domiciled in different Member States or that the subject matter of the case relates to another Member State (see Case C-281/02 Owusu [2005] I-1383, para 26). Where, for instance, the trader and the QE are established in the forum State, the international element of the dispute may stem from the fact that the alleged infringement was conducted in another State and/or affected foreign consumers. Furthermore, it must be noted that representative actions brought by public bodies (art 4(7) of the Directive) fall under the concept of 'civil and commercial matters' in art 1(1) Brussels Ia if the procedural position of public bodies, under the applicable national law, is comparable to that of a private party (see Case C-73/19 Movic BV EU:C:2020:568, paras 48-49).

25 Case C-167/00 Henkel [2002] ECR I-8111.

26 Provided that a representative action concerns 'matters relating to tort, delict or quasi-delict' within the meaning of art 7(2) Brussels Ia, the claimant's choice to sue either in the courts of the place of 'damage' or in the courts of the place where the event giving rise to the damage occurred (see Case 21/76 Bier (Mines de Potasse d'Alsace) [1976] ECR 1735) should lie with the claimant entity, given that rec 36 of the Directive expressly provides that QEs, and not the consumers concerned, shall enjoy the procedural rights and obligations of the claimant party.

27 Pato (n 2) 158-61.

28 Pato (n 2) 205.
} 
proceedings concerning the compensation of harm caused by illegal business practices to a multitude of injured parties against foreign traders.

In light of the established case law, the 'place where the event giving rise to the damage occurred' under the first prong of the Bier rule is widely neglected as a connecting factor for consolidating jurisdiction regarding damages claims arising from multi-State torts, such as product liability, incorrect disclosures by multinational corporations, anti-competitive practices, and environmental torts, for the simple reason that that place, if reliably identifiable at all, all too often coincides with the defendant's domicile. ${ }^{29}$ On the other hand, with regard to the place of 'damage', it seems axiomatic that the 'mosaic principle', according to which the competent court can rule only on the victim's alleged loss that was caused within the territories of the Member State in which that court is situated, ${ }^{30}$ must be applied accordingly where several victims, harmed by the same act, have suffered damage in different Member States. ${ }^{31}$ Moreover, the fragmentation of proceedings is reinforced by the settled case law according to which Article 7(2) Brussels Ia could not be interpreted extensively to enable the competent court to determine concurrent contractual claims arising from the alleged wrong. ${ }^{32}$ The same arguably applies, although vice versa, for the contractual head of jurisdiction under Article 7(1) Brussels Ia. ${ }^{33}$

Leaving the disputed 'mosaic principle' aside, the situation is further aggravated by the fact that the ECJ, even though by now leaning towards a market-oriented approach of allocating jurisdiction for disputes arising from infringements of securities law ${ }^{34}$ and cartel cases, ${ }^{35}$ still seems committed to

29 Amaro et al. (n 5) 98; Lein, 'Cross-Border Collective Redress and Jurisdiction under Brussels I: A Mismatch' (n 10) 134-5, paras 8.14-8.15.

${ }^{30}$ While the so-called mosaic principle has, thus far, explicitly been used by the ECJ only in cases concerning the violation of privacy and personality rights, IP rights and unfair competition (see Cases C-68/93 Shevill [1995] ECR I-415, paras 29-30; C-523/10 Wintersteiger EU: C:2012:220, para 28; C-170/12 Pinckney EU:C:2013:635, paras 43-47; C-441/13 Hejduk EU: C:2015:28, paras 27-38; C-618/15 Concurrence SARL EU:C:2016:976, paras 31-34), it is widely considered to have evolved into a general rule governing the jurisdiction of the courts at the place where the damage occurred (see, inter alia, Lein, 'Special Jurisdiction for Particular Kinds of Claims' (n 20) 171, para 4.117, arguing for the application of the mosaic approach in relation to cartel damages claims).

31 L Gorywoda, N Hatzimihail and A Nuyts, 'Introduction: Market Regulation, Judicial Cooperation and Collective Redress' in A Nuyts and N Hatzimihail (eds), Cross-Border Class Actions: The European Way (Sellier 2014) 50.

32 Case 189/87 Kalfelis [1988] ECR 5565, paras 19-21.

33 See P Mankowski, 'Article 7' in U Magnus and P Mankowski (eds), Brussels Ibis Regulation: Commentary (Otto Schmidt 2016) 160.

34 See the ambivalent ruling in Case C-709/19 Vereniging van Effectenbezitters EU: C:2021:377, paras 34-35, according to which 'only the jurisdiction of the courts of the Member States in which that company has complied, for the purposes of its listing on the stock exchange, with the statutory reporting obligations can be established on the basis of the place where the damage occurred'.

${ }_{35}$ Cases C-27/17 flyLAL-Lithuanian Airlines EU:C:2018:533, para 40; C-451/18 Tibor-Trans EU:C:2019:635, paras 32-34; Volvo (n 14) paras 31-32. 
the traditional concept of individual loss allocation with respect to 'market torts'. Thus, in such disputes, the courts of the Member State in which the affected marketplace is situated may only determine damages claims brought by individuals under the important condition that the alleged individual damage occurred within the territory of that State. ${ }^{36}$ While the ECJ has confirmed that national law might provide for a centralisation of territorial jurisdiction with respect to the damage that materialised in the forum State, ${ }^{37}$ such a consolidation of local jurisdiction is but a makeshift solution that, in the case of multi-State torts, does not exclude the threat of inherently inefficient parallel proceedings in different Member States.

Suffice to say, the conventional method of allocating jurisdiction independently for each claim, coupled with the 'mosaic principle' limiting the jurisdiction of the courts of the place where the damage occurred, creates a considerable barrier for centralising jurisdiction in a single court and, hence, promotes parallel litigation and irreconcilable judgments. In light of this, Nuyts, inter alia, proposes to notionally locate damage at the 'centre of the collective interests of the injured victims', by analogy to eDate Advertising. ${ }^{38}$ As is well known, in eDate, the ECJ essentially created a forum actoris, on the basis of the place of 'damage', for disputes concerning the allegation of infringements of personality rights by means of material on a website by allowing the putative victim to recover her or his worldwide damage in the courts at the place where the victim had the 'centre of her or his interests', which, according to the ECJ, ordinarily was the place where the victim was habitually resident. ${ }^{39}$

Drawing a loose analogy to that case law, it is argued that the courts of the Member State in which the 'centre of the collective interests of the injured victims' is based should be competent to determine collective actions brought for the compensation of harm inflicted on a multitude of victims, regardless of whether the losses materialised solely within the forum State, in several Member States or, indeed, in third States. ${ }^{40}$ To this end, Nuyts submits that eDate indicated that novel connecting factors could be created if required by the specific circumstances of the case. ${ }^{41}$ More specifically, it is argued that centralising jurisdiction in mass harm situations would contribute to the

36 See, with respect to cartel damages claims, Cases C-27/17 flyLAL-Lithuanian Airlines (n 35) para 40; C-451/18 Tibor-Trans (n 35) paras 33-34; apparently also Volvo (n 14) paras 39-42, according to which, where the damage of an antitrust victim consists of additional costs incurred because of artificially high prices, the place of purchase determines jurisdiction, and, in case of purchases made in several places, the courts of the place where the harmed undertaking has its registered office are competent to determine the action.

37 Volvo (n 14) paras 35-37.

38 Nuyts, 'The Consolidation of Collective Claims Under Brussels I' (n 16) 77-9.

39 Joined Cases C-509/09 and C-161/10 eDate Advertising and Martinez [2011] ECR I-10302, paras 48-50. The ECJ did not abandon the 'mosaic approach' for internet cases, leaving the victim the option to sue in each Member State in which the compromising material was accessible for the loss suffered in the forum State.

40 Nuyts, 'The Consolidation of Collective Claims Under Brussels I' (n 16) $78 . \quad 41$ ibid. 
principle of the sound administration of justice (Recital 16 Brussels Ia) by promoting a comprehensive determination of all damages claims in a forum that might be more accessible for the victims concerned than the court of the defendant's domicile. ${ }^{42}$

This proposal, while definitely worthy of consideration from a de lege ferenda perspective, must be rejected on the basis of the law as it stands at present.

First, hindsight suggests that eDate was an outlier. As the ECJ has now made clear, the eDate approach cannot be applied indiscriminately to other specific types of torts, such as infringements of IP rights committed on the internet, ${ }^{43}$ let alone all kinds of infringements of EU law with respect to which (crossborder) representative actions might be brought. The eDate ruling was evidently driven by the insight that the strict application of the mosaic principle, as originally developed for violations of personality rights in print media, ${ }^{44}$ to infringements of personality rights via online publications would make the place of damage irrelevant. ${ }^{45}$

Even assuming that it was possible to reliably quantify the proportion of the damage caused within any particular Member State in which the disputed online publication is or was accessible, ${ }^{46}$ any victim faced with the prospect of having to initiate separate actions in up to 27 Member States to recover its entire damage would practically be forced to sue the defendant in its domicile, particularly in light of the fact that only a court having jurisdiction to rule over the victim's worldwide damage is competent to determine an action for an injunction against the operator of the website. ${ }^{47}$ While the ECJ apparently felt forced to create the alleged victim's 'centre of interests' as an additional ground of jurisdiction to ensure adequate protection of rights of personality, at the level of jurisdiction, in an increasingly globalised and digitalised world, it has continuously sought to justify its solution by reference to the principle of proximity. ${ }^{48}$ The courts of the place of the victim's centre of interests, so the argument goes, are best placed to assess the impact that material placed online could have on an individual's personality rights. ${ }^{49}$

In fact, the key difference between the eDate reasoning and collective redress is that the required 'close link' between a collective dispute and the competent court cannot be ensured by trying to identify a so-called 'centre of the collective

42 ibid.

43 See Wintersteiger (n 30) paras 31-32; Pinckney (n 30) para 45; Hejduk (n 30) paras 36-37. In fact, the eDate approach has thus far only been extended to infringements of personality rights of legal persons committed on the internet in Case C-194/16 Bolagsupplysningen EU:C:2017:766.

44 See Shevill (n 30) paras 29-30.

45 See also the critical assessment by A Briggs, Civil Jurisdiction and Judgments (7th edn, Routledge 2021) 279-80, para 14.37.

46 Which is, however, very doubftul; see eg Lein, 'Special Jurisdiction for Particular Kinds of Claims' (n 20) 169, para 4.112.

48 eDate (n 39) paras 40, 48; see also Case C-800/19 Mittelbayerischer Verlag EU:C:2021:489, paras $40-41$.

49 eDate (n 39) para 48. 
interests' by relying on any particular geographical connecting factor, such as the place where the majority of the victims is resident, the place where the greater part of all the damages materialised or, worse still, the place where the entity taking action on behalf of the victims is established. ${ }^{50}$ In fact, establishing competence by relying on any one of the aforementioned factors necessarily leads to 'spillover effects', ${ }^{51}$ allowing the competent court to rule over damages regardless of whether the relevant activity or the individual damages suffered by one or more of the victims represented in the action occurred within the territory of the Member State within which the court seised is situated.

Furthermore, the suggested 'consolidation rule' begs the question of which court shall be given competence if, at least on the basis of an ex ante assessment, two or more Member States appear equally affected by the disputed mass or market tort. ${ }^{52}$ Trying to circumvent this problem by allowing the courts of each Member State in whose territories a significant proportion of the total damage materialised to rule over the totality of the losses of all the victims affected by the multi-State tort, provided that this was consistent with the overriding objectives of proximity and legal certainty, ${ }^{53}$ is tantamount to an admission that the opaque 'centre of gravity' of a collective dispute cannot be clearly identified by having recourse to any abstract criteria but, if at all, on the basis of an overall assessment of the circumstances of each case, as outlined below. 54

In light of the above, it is evident that the solution suggested by Nuyts comes down to the introduction of a forum attractivitatis or forum connexitatis hitherto unknown in the Brussels regime. Clearly, Article 8(1) Brussels Ia, according to which a court having jurisdiction to entertain claims against an 'anchor' defendant can determine claims brought against other defendants only by reason of the fact that the claims are so closely connected that, if decided separately, there would be a risk of irreconcilable judgments, militates for an argumentum e contrario rather than for devising novel grounds for 'derived' jurisdiction such as a 'centre of the collective interests' for mass torts or cross-border infringements of EU consumer law. ${ }^{55}$ As AG Sánchez Bordona correctly noted in his opinion in Vereniging van Effectenbezitters, it is not for

\footnotetext{
50 However, cf Halfmeier and Rott (n 16) 250; see also Nuyts, 'The Consolidation of Collective Claims Under Brussels I' (n 16) 79.

51 This is conceded by Nuyts, 'The Consolidation of Collective Claims Under Brussels I' (n 16) 78.

52 The same applies to a possible future conflict of laws rule designed to consolidate the applicable laws in class actions; see R Michaels, 'European Class Actions and Applicable Law' in A Nuyts and N Hatzimihail (eds), Cross-Border Class Actions: The European Way (Sellier 2014) $111,135$.

53 See Nuyts, 'The Consolidation of Collective Claims Under Brussels I' (n 16) 78; similarly Röthemeyer (n 16) 47.

54 See Section V.B.

55 See also Case C-51/97 Réunion Européenne [1997] ECR I-6534, paras 46-52; Kalfelis (n 32) paras 8-9.
} 
the ECJ to invent ad hoc grounds of jurisdiction for the sole purpose of easing collective redress. ${ }^{56}$ Rather, it is for the legislator alone to address the issue of how best to promote collective redress within the jurisdictional framework in light of the competing policy objectives mentioned above. ${ }^{57}$

In fact, there is little room to facilitate joint treatment of a multiplicity of similar claims of dispersed victims in a neutral court by refining the approach to locating the 'initial damage' and the harmful event giving rise to it with respect to some particular torts that are a frequent source of mass harm. Where, for instance, multiple consumers have suffered harm as a result of the use of a particular product, competence should be conferred, under the first prong of Article 7(2) Brussels Ia, and in contrast to the Kainz ruling, ${ }^{58}$ to the courts of the Member State or the Member States in whose territories the goods are purposefully 'marketed',59 ie, offered for sale to the final purchasers and not merely advertised. ${ }^{60}$ Using 'marketing', as referred to in all three heads of the cascade in Article 5(1) of the Rome II Regulation ${ }^{61}$ instead of 'manufacturing' — as the essential connecting factor for attributing jurisdiction not only would ensure that the first prong of Article 7(2) Brussels Ia is not rendered meaningless in situations where the goods in question are either manufactured at the defendant's production sites or outside the EU but also could pave the way for a joining of similar damages claims in a single forum that might particularly suit the victims' interests.

Another example is securities law. In contrast to the ECJ's wayward approach of identifying the place of 'damage' under Article 7(2) Brussels Ia in disputes regarding inaccurate investor information, ${ }^{62}$ it seems appropriate to confer jurisdiction to the courts of the Member State in whose regulated market the transaction giving rise to the investor's loss was executed. ${ }^{63}$ This market-oriented approach corresponds to the rationale of the informational duties placed on issuers and offerors of financial instruments, namely, to ensure the allocative efficiency of financial markets, and at the same time facilitates the grouping of claims of investors who purchased or sold the securities in question on the same regulated market.

\footnotetext{
56 AG Sánchez Bordona, Opinion on Case C-709/19 Vereniging van Effectenbezitters EU: C:2020:1056, para 95 .

58 Case C-45/13 Kainz EU:C:2014:7, paras 26-29, 33.

57 See Section I. Rome II Regulation’ (2008) 57 ICLQ 899, 904.

61 Regulation (EC) No 864/2007 of the European Parliament and of the Council of 11 July 2007 on the law applicable to non-contractual obligations (Rome II) [2007] OJ L199/40.

62 Cases C-375/13 Kolassa EU:C:2015:37; C-304/17 Löber EU:C:2018:701; Vereniging van Effectenbezitters (n 34); for a critical appraisal of the case law, see eg M Gargantini, 'Competent Courts of Jurisdiction and Applicable Law' in D Busch, G Ferrarini and JP Franx (eds), Prospectus Regulation and Prospectus Liability (Oxford University Press 2020) 455-8, paras 19.39-19.49.

${ }^{63}$ See AG Sánchez Bordona, Opinion on Case C-709/19 Vereniging van Effectenbezitters EU: C:2020:1056, paras 37-38.
} 


\section{B. Aggregating Contractual Claims in the Fora of Article 18(1) and Article 7} (1) Brussels Ia

First, it must be recalled that the ECJ, building on its previous case law, ${ }^{64}$ finally clarified in Schrems that no one other than the consumer who was a party to the contract to which the claim in question relates can avail themselves of the special fora of Article 18(1) Brussels Ia. ${ }^{65}$ Since the jurisdiction of the consumer forum is thus necessarily limited to determining the consumer's own rights arising from the contract concluded between the consumer and the trader, it is impossible for a consumer-assignee to assert claims assigned by other consumers against the same trader in either the consumer-assignee's court or in the consumer-assignor's court. ${ }^{66}$ While several scholars have argued for a more expansive interpretation of Articles 17-19 Brussels Ia according to which a representative consumer claimant should be entitled to bring proceedings against a trader with respect to claims arising from a multitude of consumer contracts in the courts of the place where any one of the consumers concerned is domiciled, ${ }^{67}$ it is by now widely accepted that the special protective jurisdiction granted to consumers in Title II, Section 4, Brussels Ia, is generally inapplicable to legal persons, be they consumer associations or private companies. ${ }^{68}$ Any other conclusion could hardly be reconciled with the wording, let alone the logic, of the provisions on consumer contracts that are specifically designed to offset the presumed structural imbalance between the parties to the contract. ${ }^{69}$

Article 7(1) Brussels Ia does not provide a viable alternative for aggregating contractual claims: even assuming that QEs might avail themselves of the special jurisdiction of Article 7(1) Brussels Ia in proceedings brought for the purpose of enforcing claims arising from consumer contracts without acting as assignees, ${ }^{70}$ the connecting factors employed under Article 7(1)(a) and Article 7(1)(b) Brussels Ia are apt to result in there being a multiplicity of fora, each competent to rule only on the claims that relate to obligations to be performed within their respective jurisdiction. ${ }^{71}$ Attempting to circumvent the relationship-specific approach of determining jurisdiction by constructing a

\footnotetext{
64 Case C-89/91 Shearson Lehman Hutton [1993] ECR I-00139, paras 19, 23-24; Henkel (n 25) paras 32-33. $\quad{ }_{65}$ Schrems (n 22) para 44. $\quad{ }_{67}$ Schrems (n 22) paras 47-49.

67 See Danov (n 8) 376-7; P Mankowski and P Arnt Nielsen, 'Introduction to Articles 17-19' in U Magnus and P Mankowski (eds), Brussels Ibis Regulation: Commentary (Otto Schmidt 2016) 451 .

68 See Henkel (n 25) paras 32-33; Briggs (n 45) 149-50, para 10.08; TC Hartley, Civil Jurisdiction and Judgments in Europe (Oxford University Press 2017) para 11.67.

69 See Case C-464/01 Gruber [2005] ECR I-439, para 34.

70 However, cf B Hess, Europäisches Zivilprozessrecht (2nd edn, De Gruyter 2021) 828, para 11.79; Lein, 'Special Jurisdiction for Particular Kinds of Claims' (n 20) 145, paras 4.37-4.38.

71 Art 7(5) Brussels Ia hardly offers a promising route for grouping claims arising from crossborder infringements of EU law, given that corporate traders often run their commercial activities in a variety of different branches (see Lein, 'Cross-Border Collective Redress and Jurisdiction under Brussels I: A Mismatch’ (n 10) 136, para 8.20).
} 
'centre of gravity' with respect to a multiplicity of contracts concluded by different consumers, by analogy to the ECJ rulings in Color Drack ${ }^{72}$ and Wood Floor Solutions, ${ }^{73}$ is bound to fail for the reasons set out above in relation to a possible centralisation of tort jurisdiction.

Crucially, the reasoning advanced by the ECJ for centralising jurisdiction under Article 7(1)(b) Brussels Ia with respect to individual contracts for the sale of goods and contracts for services to be performed in different places is based on the assumption that the principal place of delivery and the place of the main provision of services provide a sufficiently close linking factor between the contract at issue and the designated court. ${ }^{74}$ However, constructing a 'centre of gravity' in relation to multiple contracts concluded by a mass of consumers with the same trader evidently serves the purpose only of facilitating the administration of collective actions while necessarily compromising the aim of identifying a close link between any particular contract and the competent court. ${ }^{75}$

In addition, as with the proposal to centralise jurisdiction in multi-State tort cases, the approach relying on a principal place of performance immediately raises the question of which criteria ought to be used for geographically locating a notional 'centre of gravity' with respect to a multiplicity of substantially similar yet independent contracts between different parties. Ultimately, the search for that fictitious place would, if only by default, most likely end up at the trader's domicile, the result being that Article 7(1) Brussels Ia could not be invoked for establishing jurisdiction for a representative action brought for the purpose of enforcing contractual claims in any case.

\section{Consolidation of Jurisdiction through Choice-of-Court Agreements}

Finally, any attempt to centralise jurisdiction for collective redress by means of choice-of-court agreements concluded between a trader and a representative is equally fraught with difficulties given that such agreements are unlikely to be enforceable against any one of the consumers concerned without her or his express consent. Taking stock of the ECJ's generally restrictive policy regarding third-party effects of choice-of-court agreements, ${ }^{76}$ it is very unlikely that a consumer association would be considered to have the power to bind absent consumers by way of choice-of-court agreements concluded with a trader, regardless of whether the law of the chosen court provides for an opt-in or opt-out scheme.

72 Case C-386/05 Color Drack [2007] ECR I-03699.

73 Case C-19/09 Wood Floor Solutions [2010] ECR I-02121.

${ }_{74}$ Color Drack (n 72) para 40; Wood Floor Solutions (n 73) paras 31-33.

75 Tang (n 8) 118.

76 See eg Case C-112/03 Société financière et industrielle du Peloux [2005] ECR I-3707, paras 38-43; see also Case C-519/19 Ryanairv DelayFix EU:C:2020:933, paras 42, 46-47. 


\section{DEALING WITH PARALLEL MASS LITIGATION DE LEGE LATA}

Given that the jurisdictional framework of Brussels Ia is thus likely to promote the occurrence of competing collective and individual actions, it becomes all the more important to examine how the present law deals with the threat of parallel representative actions. Closer analysis shows that whilst a purposive interpretation of the rules on lis pendens and related actions should mitigate the threat of inexpedient concurrent litigation to some extent, the 'first in time rule' entrenched in Articles 29 and 30 Brussels Ia is clearly not a satisfactory basis for dealing with collective redress proceedings.

In the absence of ECJ case law on this point, the key issues to consider are whether and, if so, under which conditions (i) parallel individual and collective proceedings and (ii) (partially) overlapping representative actions are governed by either Article 29 Brussels Ia or Article 30 Brussels Ia. ${ }^{77}$ The importance of the distinction is obvious, given that it determines whether any court other than the court first seised must stay its proceedings and, once the court previously seised has accepted jurisdiction, cede jurisdiction to that court pursuant to Article 29(3) Brussels Ia or whether the second court may, at its discretion, stay its proceedings under Article 30(1) Brussels Ia or, if applicable, dismiss the action for consolidation pursuant to Article 30(2) Brussels Ia.

A comparatively simple matter in this context is verifying whether concurrent representative actions and simultaneously pending collective and individual proceedings share the 'same cause of action' for the purposes of the application of Article 29(1) Brussels Ia or, alternatively, whether the actions at issue are 'related' within the meaning of Article 30(3) Brussels Ia. As far as two representative actions are brought on behalf of the same groups of consumers and seeking to enforce claims arising from the same disputed infringement of EU law, the intertwined requirements that both actions must have the same object and share the same factual and legal basis ${ }^{78}$ should be easily met. On the other hand, while the threat of incompatible judgments competing for recognition should not arise as far because two collective actions represent different groups of consumers, the actions may nonetheless be deemed 'related' in the sense of Article 30(3) Brussels Ia, particularly if the actions are based on the same business practice by the same defendant. ${ }^{79}$

By the same token, an action for a negative declaratory judgment according to which the trader is not liable to the consumers represented in a competing representative action seeking to have the trader held liable for the disputed infringement of EU law share the same 'cause' and 'object' in the sense of

77 See Danov (n 8) 380-4; B Hess, 'A Coherent Approach to European Collective Redress' in D Fairgrieve (ed), Extraterritoriality and Collective Redress (Oxford University Press 2012) 115-7, paras 6.23-6.28; J Stefanelli 'Parallel Litigation and Cross-Border Collective Actions under the Brussels I Framework: Lessons from Abroad' in D Fairgrieve (ed), Extraterritoriality and Collective Redress (Oxford University Press 2012) 147-69, paras 9.13-9.72; Tang (n 8) 124-9.

78 See Case C-406/92 The Tatry [1994] ECR I-5439, paras 36-40.

79 See Tang (n 8) 124-5, 127-8. 
Article 29(1) Brussels Ia. ${ }^{80}$ The most pressing issue is, however, whether a representative body and any individual on whose behalf a representative action is brought can be treated as 'the same parties' within the meaning of Article 29(1) Brussels Ia and, furthermore, whether the autonomous concept of 'parties' should be interpreted as applying to the beneficiaries of overlapping collective actions.

\section{A. A Wider Concept of 'The Same Parties' in Article 29(1) Brussels Ia}

Whilst frequently doubted, ${ }^{81}$ it is indeed plausible to construe the term 'the same parties' in Article 29(1) Brussels Ia extensively in the context of collective redress proceedings, meaning that a beneficiary represented in a collective action pending in one Member State is precluded from suing the same defendant with respect to the rights asserted in the prior proceedings in the courts of another Member State. ${ }^{82}$ In light of the fact that the outcome of a representative action for redress measures (and, indeed, a court-approved settlement between a QE and a trader) potentially acquires the force of res judicata against the consumers concerned, the ruling in Drouot, pursuant to which an insurer and the insured party ought to be treated as 'the same parties' where the outcome of the action brought or defended by one of them, as in the case of proceedings brought by way of subrogation, ${ }^{83}$ would also affect the legal position of the other, militates for this wide interpretation of the term 'the same parties'. If, following Drouot, it is correct to treat the assignor and the assignee as the same party with respect to parallel litigation concerning the assigned rights, ${ }^{84}$ the same should apply where a QE seeks to enforce individual rights by way of a representative action on behalf of consumers who simultaneously assert the same claims against the same trader individually or collectively.

This view is further supported by Article 9(4) Directive (EU) 2020/1828, according to which Member States are obliged not only to ensure that the consumers represented in a representative action can neither sue the same trader individually nor be represented in another representative action with the same cause of action but also to take measures to avoid the threat of a 'double compensation' of the consumers on whose behalf the action is brought. With regard to the wording and purpose of that provision, it would be wrong to limit its scope to purely 'domestic settings'. Rather, the second sentence of Article 9(4) of the Directive suggests that a judgment delivered in collective redress proceedings in one Member State must not be enforced in the

${ }^{80}$ Following The Tatry (n 78) paras 41-44.

81 Danov (n 8) 381; Tang (n 8) 126.

82 Stefanelli (n 77) 155 , paras 9.32-9.33.

83 Case C-351/96 Drouot Assurances [1998] ECR I-3075, para 19.

84 Karen Holdings Ltd v Rodette Commerce Ltd [2008] 1 Lloyd's Rep 434; R Fentiman, 'Article 29' in U Magnus and P Mankowski (eds), Brussels Ibis Regulation: Commentary (Otto Schmidt 2016) 727-8. 
Member State addressed to the extent that the requested enforcement has the effect of overcompensating a consumer already entitled to compensation on the basis of another judgment that is enforceable in the latter State. This, however, can be ensured effectively only if the courts of the Member State addressed are competent to deny recognition and enforcement on the grounds of Article 45(1)(c), (d) Brussels Ia, which implies that the representative body that obtained the judgment for which enforcement is sought and a consumer on whose behalf the action was brought must be treated as 'the same parties' under those provisions. Logic dictates that the same expansive interpretation should prevail under Article 29 Brussels Ia.

It may be argued, of course, that the threat of conflicting judgments arising from parallel representative and individual actions might in any event be avoided by having recourse to Article 30 Brussels Ia. Of particular utility in this instance would be an interpretation in conformity with Article 9(4) of the Directive, according to which the second court seised is effectively compelled to stay its proceedings to prevent conflicting decisions possibly arising from parallel representative and individual actions. Notwithstanding that, the more consistent interpretation is to treat a $\mathrm{QE}$ bringing representative actions and the beneficiaries of that action as 'the same parties' under the conditions set out above, given that Article 29 Brussels Ia, displacing Article 30 Brussels Ia under the lex specialis rule, is specifically designed to overcome the risk of conflicting judgments competing for recognition. ${ }^{85}$

That said, since the interests of a $\mathrm{QE}$ and any consumer on whose behalf a representative action is brought can be considered identical and indissociable only as far as the QE seeks to enforce the very rights that are the subject matter of simultaneously pending individual or collective proceedings, it is evident that a representative action for redress measures may well proceed for the purpose of asserting individual rights that are not the subject matter of any competing individual or collective action; as is clear from The Tatry, ${ }^{86}$ the term 'the same parties' is separable where several different natural or legal persons are involved in each of the parallel proceedings. ${ }^{87}$

\section{B. Implications for Actions for Negative Declaratory Relief}

Furthermore, it should be emphasised that treating a QE and a consumer represented in a representative action as 'the same parties' in the sense of Article 29(1) Brussels Ia does not necessarily imply that a trader, facing putative claims by a mass of consumers, could, by instituting proceedings against a $Q E$ seeking a declaration that the trader was not liable to the consumers concerned, effectively pre-empt individual and representative actions that might be brought against the trader with respect to the business practice forming the subject matter of the prior proceedings. While some

\footnotetext{
85 Fentiman (n 84) 714, 725-6. $\quad{ }^{86}$ The Tatry (n 78) paras 33-34. $\quad{ }^{87}$ Tang (n 8) 125.
} 
scholars indeed suggest that such an action, at least if brought in a Member State that adopted an opt-out mechanism for compensatory collective actions, might be used for thwarting collective redress proceedings, ${ }^{88}$ that proposition is, with respect, debatable.

First, the procedural principle of 'equality of arms' does not entail that collective redress, which is primarily aimed at increasing consumers' access to justice by overcoming the 'rational apathy' of consumers in light of the cost risks associated with individual litigation, ${ }^{89}$ must inevitably operate in reverse to allow a trader to obtain a judgment having the force of res judicata against absent consumers that might potentially bring claims with respect to the disputed infringement of EU law to which the action for negative declaratory relief brought against a representative body relates. ${ }^{90}$ However, even assuming that the judgment delivered in an action for negative declaratory relief defended by a QE had the force of res judicata against the consumers affected by the business practice at issue, the 'representation power' of a QE would necessarily be qualified by analogy to Article 9(4) Directive (EU) 2020/1828.

If consumers resident in Member States other than that in which a representative action for redress measures is pending will not be bound by the outcome of the action unless they gave their express consent to be represented in the action, foreign consumers must a fortiori be protected in an equivalent manner against unwarranted representation by a QE that purports to defend their interests in an action for a negative declaratory judgment brought by a trader. Thus, regardless of whether proceedings are brought by a QE against a trader or vice versa, a consumer who is not domiciled in the forum State will never be bound by the judgment delivered by the court seised or, alternatively, by a court-approved settlement unless she or he explicitly accepts being bound by the outcome of the proceedings in accordance with the procedural law of the court seised.

\section{Competing Collective Actions}

In light of the foregoing, it seems only logical to interpret the term 'the same parties' in Article 29 Brussels Ia as applying not only to the actual parties to the dispute but also to the beneficiaries represented in (partially) overlapping collective actions so as to effectively avoid the danger that recognition of the judgments delivered in the pending proceedings might be denied by courts in other Member States pursuant to Article 45(1)(d) Brussels Ia. ${ }^{91}$ Accordingly, Article 29 Brussels Ia applies when competing representative actions are

\footnotetext{
88 See Hess, Europäisches Zivilprozessrecht (n 70) 830, para 11.84; Stefanelli (n 77) 156-7, para 9.36.

${ }_{90}$ Contra Hess, Europäisches Zivilprozessrecht (n 70) 830, para 11.84.

91 Similarly, Tang (n 8) 126-7.
} 
brought for the purpose of enforcing the same claims of the same groups of consumers, while the requirement of 'relatedness' is arguably met when two collective actions are brought on behalf of different groups of consumers but seek to enforce claims arising from the same allegedly illegal business practice.

However, regardless of whether Article 29 or Article 30 Brussels Ia is deemed applicable to (partially) overlapping representative actions, it is of paramount importance to clearly determine which court is first seised according to Article 32(1) Brussels Ia. Since the requirements of 'congruence' and 'relatedness', as stated, need to be verified with regard to the classes of consumers on whose behalf representative actions are brought, the determination of the date of seisin necessarily depends on the respective collective redress mechanism employed. For opt-out schemes, seisin is arguably triggered when the collective proceedings are formally initiated by the representative body, provided that the requirements set out under the first or second limb of Article 32(1) Brussels Ia are met and that the beneficiaries of the action are sufficiently clearly identified, irrespective of whether individual consumers subsequently withdraw from the proceedings. This approach provides legal certainty without undermining access to justice, provided that the lex fori ensures that the consumers concerned are adequately informed of pending representative actions, as required by Article 13(2) Directive (EU) 2020/1828.

Where the proceedings are based on an opt-in mechanism, a more nuanced solution is required. While the formal initiation of the proceedings determines seisin regarding consumers who have expressed their wish to be represented in the proceedings in advance, a court can be treated as seised of the claims of consumers who subsequently participate in an ongoing representative action $^{92}$ only at the date when the individual consumer lodges the statement expressing her or his wish to be represented in the action. Arguably, seisin must be determined in the latter situation in accordance with the general rules governing the seisin of amended claims: If it is correct that a court is not seised of any amended claims until the date when the amendment is made, ${ }^{93}$ the same must prevail with respect to claims asserted by a representative body on behalf of consumers who subsequently take part in the pending proceedings given that only the consumer's mandate allows the representative to litigate over the consumer's claims in an opt-in procedure.

As regards the exercise of the discretion granted under the first or second limb of Article 30 Brussels Ia, it seems generally appropriate for the second court to stay proceedings if the prior proceedings are brought on behalf of a greater class of consumers from several Member States, in the courts of the Member State in

92 See Directive (EU) No 2020/1828 (n 4) rec 44.

93 See P Rogerson, 'Lis Pendens and Related Actions' in A Dickinson and E Lein (eds), The Brussels I Regulation Recast (Oxford University Press 2015) 345, para 11.65. 
which the defendant is domiciled or in which the harmful event occurred. ${ }^{94}$ A major weakness of the existing rules is, however, that they do not provide for a consolidation of related actions in any other court but the court first seised, even if a centralisation of proceedings in another court, in light of the particular circumstances of the case, seems reasonable in terms of procedural expediency and to effectively avoid any risk of inconsistent judgments. ${ }^{95}$

Imagine, for instance, that a cross-border representative action is brought following damages inflicted by a harmful product upon victims from several Member States in the courts of the place where the producer is established at a time when another domestic representative action brought on behalf of a small minority of all the victims is already pending in another Member State: Would it not be sensible to introduce rules that empower the respective courts, of their own motion or upon application by one of the parties, to consolidate proceedings in the court that, on an ex ante assessment, seems best placed to hear and decide on all claims together, namely, in the above example in the court at the place where the producer is domiciled? This leads directly to the question of which measures need to be introduced, on the whole, to better align the current jurisdictional system with Directive (EU) No 2020/1828.

\section{EVALUATION OF CENTRALISED MODELS OF JURISDICTION}

The foregoing analysis confirms that the general discontent with the way collective redress proceedings can be dealt with under the Brussels regime is, at least to some extent, justified. The need to verify jurisdiction independently and separately for each claim and each claimant or beneficiary of a representative action on the basis of the existing special grounds of jurisdiction, namely, Articles 7(1), (2), (5) and 18(1) Brussels Ia, tends to promote decentralised proceedings. The rules on lis pendens and related actions, even if reinterpreted as suggested above, ${ }^{96}$ cannot exclude the risk of inefficient parallel mass proceedings raising the same questions of fact and law but, rather, stimulate an undesirable 'race to the courtroom'.

It is therefore necessary to explore how the current law should be amended to better respond to the needs of cross-border collective redress while maintaining the principles on which the jurisdictional system is based, these being, first and foremost, the objectives of 'proximity and predictability'. According to widespread opinion, the twofold aim of promoting effective private enforcement of EU substantive law through collective redress and ensuring the sound administration of justice is best met by introducing a centralised model of jurisdiction specifically designed for collective disputes. ${ }^{97}$

\footnotetext{
94 Tang (n 8) 128-9.

95 Danov (n 8) 383-4, 392-3; see also Hess, 'A Coherent Approach to European Collective Redress' (n 77) 115-17, paras 6.25-6.28.

96 See Section III.

97 See eg Amaro et al. (n 5) 109-10; Stefanelli (n 77) 155-6, para 9.34; see also Lein, 'CrossBorder Collective Redress and Jurisdiction under Brussels I: A Mismatch' (n 10) 142, para 8.36.
} 
While some commentators argue for giving exclusive competence to the courts of the defendant's domicile, others call for the introduction of a special forum of choice, more specifically by allowing the consumers and/or their representatives to bring proceedings in the forum at the 'centre of the affected group's main interests' or in the courts of the place where the litigating QE is established. Although the EU has thus far refrained from adopting any specific legislative measures in the area of jurisdiction for the purpose of strengthening collective redress mechanisms, the endeavour to ensure procedural efficiency by implementing a centralised model of jurisdiction for EU representative actions might gain further political momentum in the wake of the transposition of Directive (EU) No 2020/1828 into national law and possibly become a key priority for EU policymakers in the course of the forthcoming revision of Brussels Ia.

With special regard to the twofold objective mentioned above, this section assesses the merits and drawbacks of a possible centralisation of jurisdiction for collective redress proceedings. While a 'consolidation rule' seems superficially attractive, especially for the purpose of countering parallel mass proceedings, there are several problems with all the proposals submitted thus far.

\section{A. Conferring Exclusive Jurisdiction to the Courts of the Defendant's Domicile}

A first possible rule, even though it has been largely rejected in the academic literature to date, ${ }^{98}$ is to confer exclusive jurisdiction to the courts of the defendant's domicile with respect to representative actions falling under Directive (EU) No 2020/1828 or, going further, with respect to all types of collective redress proceedings. ${ }^{99}$ Despite the conventional criticism of this approach, there is, at first sight, much to be said for this proposal. It neatly corresponds to the very principle on which the jurisdictional framework is said to rest, actor sequitur forum rei, ${ }^{100}$ while the objection that centralising jurisdiction at the corporate trader's seat inappropriately curtails consumers' access to justice ${ }^{101}$ has certainly lost some of its validity since the Directive has entered into force.

With regard to the fact that all Member States are obliged to put into place measures aimed at ensuring that QEs are not refrained from efficiently

98 Lein, 'Cross-Border Collective Redress and Jurisdiction under Brussels I: A Mismatch' (n 10) 113, 142, paras 8.11-8.12, 8.37; Nuyts, 'The Consolidation of Collective Claims Under Brussels I' (n 16) 78; Pato (n 2) 213-14.

99 See draft report by G Didier on 'Representative actions for the protection of the collective interests of consumers: Proposal for a Directive (COM(2018)0184 - C8-0149/2018 - 2018/0089 (COD)' (European Parliament, Committee on Legal Affairs, 8 November 2018) 120-1, Amendment $222<$ www.europarl.europa.eu/sides/getDoc.do?pubRef=-//EP//NONSGML + COMPARL+PE-630.422+01+DOC+PDF+V0//EN\&language=EN $>$.

100 See only Case C-189/08 Zuid-Chemie [2009] ECR I-6917, paras 20-21.

101 Nuyts, 'The Consolidation of Collective Claims Under Brussels I' (n 16) 78; Pato (n 2) 214. 
exercising their right to bring either domestic or cross-border representative actions based on infringements of EU law (Article 20(1) of the Directive), one might argue that this consolidation rule no longer creates a substantial barrier for consumer associations to obtain redress on behalf of consumers but, rather, contributes to effectively countering vexatious litigation by excluding the claimant's power to choose between different objectively available fora. Centralising jurisdiction in the courts of the Member State where the trader is domiciled thus seems to ensure the utmost legal certainty for all parties involved and to generate significant economies of scale by avoiding the need for multiple litigation.

Nevertheless, the European legislator should be wary of adopting this proposal. One disadvantage of the proposal is that what is gained in terms of perceived procedural expediency may be lost by eliminating the judicial power of a more closely connected forum that, as far as a grouping of claims is possible under the special heads of jurisdiction at all, might be better placed to determine the claims of a group of consumers harmed by the defendant's activities. ${ }^{102}$ With regard to the principle of the sound administration of justice (Recital 16 Brussels Ia), the proposal to attribute exclusive jurisdiction to the courts of the defendant's domicile seems all the more ambiguous, given that it necessarily entails eliminating the special head of jurisdiction under Article 8(1) Brussels Ia and thus increases the risk of parallel proceedings in cases concerning illegal activities committed by a network of business partners. ${ }^{103}$ Another disadvantage is that using the defendant's domicile as the sole connecting factor for establishing jurisdiction is particularly apt to create situations where the competent court would have to apply foreign law pursuant to the Rome I Regulation ${ }^{104}$ or the Rome II Regulation, ${ }^{105}$ which, needless to say, is not conducive to a procedurally expedient resolution of the dispute.

Even more importantly, consumers' access to justice might indeed be undermined by this concentration rule given that the determination of jurisdiction in civil actions pursued against non-EU domiciliaries falls within the domain of the Member States (Article 6(1) Brussels Ia). Since it cannot be readily assumed that the courts of all the Member States will be able, under the applicable national law, to assert jurisdiction over infringements of EU law committed by traders residing outside the EU, consumers and their representatives might indeed be forced to sue traders from third States outside the EU where effective collective redress might not be available. As a result, this proposal, if not accompanied by an 'escape clause' providing for a

\footnotetext{
102 Tzakas (n 8) 1155-6.

103 Hess, ‘A Coherent Approach to European Collective Redress' (n 77) 117, para 6.29.

104 Regulation (EC) No 593/2008 of the European Parliament and of the Council of 17 June 2008 on the law applicable to contractual obligations (Rome I) [2008] OJ L177/6.

105 See above, at (n 61).
} 
forum necessitatis in the EU, unduly favours traders from third States and thereby creates an incentive for businesses to move outside the EU. ${ }^{106}$

Finally, conferring exclusive jurisdiction to the courts at the trader's domicile can hardly be justified from a policy perspective with respect to torts that are an important source of mass harm, such as anti-competitive practices, but are not covered by Directive (EU) No 2020/1828, given that Member States are not required to adopt or retain efficient collective redress mechanisms with respect to mass or market torts in general.

\section{B. Introducing a Special Jurisdiction at the 'Centre of the Group's Main Interests'}

While the proposal to invent a novel ground of jurisdiction at the 'centre of the affected group's main interests' must be rejected on the basis of the law as it stands for all the reasons stated above, ${ }^{107}$ it is an entirely different question whether such a special jurisdiction for collective redress should be introduced de lege ferenda. However, as already indicated, the suggestion to establish jurisdiction by means of the 'centre of interests' as a connecting factor suffers from several drawbacks.

First, the elusive concept of a 'centre of the affected group's main interests' raises important questions regarding the overriding goal of ensuring a high degree of predictability, transparency and legal certainty in the area of jurisdiction as encapsulated in Recitals 15 and 16 Brussels Ia. While it may seem plausible to geographically locate the 'centre of interests' of a natural person in the Member State in which that person is domiciled or habitually resident, ${ }^{108}$ the attempt to spatially assign the 'centre of the main interests' of a multitude of victims from several Member States to one particular State amounts to a haphazard exercise.

It is telling that the proponents of centralising jurisdiction in the 'centre of gravity' shirk the task of precisely determining its situs, conceding that it is a 'delicate issue'. ${ }^{109}$ The suggested solutions, namely, (i) the Member State in which the most affected market is situated, (ii) the State in which the majority of the victims are domiciled, (iii) the State in which the greater part of the damages occurred, and (iv) the State in which the harmful activity occurred, ${ }^{110}$ might work in clear-cut cases. However, it is evident that all the factors discussed are apt to favour both consumers and corporate traders resident in the larger Member States, ${ }^{111}$ thereby considerably reducing the perceived advantage the consolidation rule would be said to offer the putative victims and their representatives.

\footnotetext{
106 See Tzakas (n 8) 1156.

107 See Section II.A.

108 eDate (n 39) para 49.

109 See Amaro et al. (n 5) 110.

110 Amaro et al. (n 5) 110. See also Lein, 'Cross-Border Collective Redress and Jurisdiction under Brussels I: A Mismatch’ (n 10) 142, paras 8.36-8.37.

111 Conceded by Nuyts, 'The Consolidation of Collective Claims Under Brussels I' (n 16) 79.
} 
The infamous 'Dieselgate' case clearly illustrates the shortcomings of the suggested use of the 'centre of interests' as a connecting factor. As a reminder, in its Volkswagen judgment, the ECJ held that a final buyer who purchased a Volkswagen car equipped with a 'carbon emissions test defeat device' suffered loss in the form of the difference between the price paid and the actual value of the deficient vehicle at the time and in the place where she or he purchased the car from a third party and could accordingly sue the manufacturer in the courts of the place where the purchase was made. ${ }^{112}$ Imagine now that a $\mathrm{QE}$ wished to initiate proceedings for the compensation of losses suffered by consumers who purchased these vehicles in different Member States. Applying the criteria mentioned above, the 'centre of gravity' could not have been located anywhere other than Germany; not only where, most likely, the majority of the cars were sold but also where the manufacturer had its domicile (within the meaning of Article 63(1) Brussels Ia). Hence, the suggested use of the 'centre of the group's main interests' would not have offered the option of initiating collective redress proceedings in a neutral forum. However, taking into account that this 'consolidation rule' for collective redress would necessarily be without prejudice to the facultative jurisdiction of the courts of each Member State in which any buyer suffered her or his financial loss to rule over the individual buyer's damage that occurred within the territory of the forum State, ${ }^{113}$ it is fallacious to assume that the creation of a 'centre of the group's main interests', if clearly identifiable at all, would considerably reduce the threat of parallel litigation in mass harm situations.

Furthermore, since such a special jurisdictional rule, if adopted, would be bound to fail in all situations where a 'centre of the group's main interests' cannot be reasonably clearly located in the territory of one particular Member State in advance by relying on any one of the aforementioned geographical connecting factors, a default rule would be necessary in any case. As far as the defendant's domicile is proposed as a subsidiarily applicable connecting factor for attributing jurisdiction, ${ }^{114}$ it suffices to note that this entails all the drawbacks mentioned above.

Rather than constructing a 'centre of gravity' of the collective dispute based on poorly defined abstract criteria, it thus appears preferable to identify the court best placed to determine common questions of law and fact of the claims of the affected group of victims or consumers by an overall assessment of the

112 Case C-343/19 Volkswagen EU:C:2020:534, paras 35, 40.

113 To hold otherwise would unduly discriminate against consumers domiciled in smaller Member States, thereby undermining the right to an effective remedy enshrined in art 47 of the Charter of Fundamental Rights of the European Union (2012/C 326/02). In addition, while art 6 (2) of the Directive ensures that QEs designated in different Member States may join forces in a single cross-border representative action brought against the same trader in respect of infringements of EU law affecting the collective interests of consumers in a number of Member States, the Directive does not preclude the right of each QE to act on its own as regards crossborder infringements of EU law.

114 See Amaro et al. (n 5) 110. 
circumstances of the collective dispute at issue. As argued in the next section, this 'holistic approach' better complies with the principles on which the jurisdictional system rests and at the same time properly promotes the policy objectives of the Representative Actions Directive.

\section{A Forum Actoris for Representative Actions?}

An all too easy way of avoiding the problems discussed above is to establish an outright forum actoris by using the representative's domicile as the connecting factor for establishing jurisdiction in collective proceedings. ${ }^{115}$ While that solution seemingly offers the best of all worlds for consumer associations, it is evident that centralising jurisdiction in the representative's domicile would upset the very balance of interests that the jurisdictional framework seeks to achieve. Member States that are eager to attract mass litigation might purposefully lay down minimum requirements for legal standing, thereby allowing ad hoc entities to bring proceedings against foreign traders with respect to commercial activities that bear no connection to the forum State. Instead of ensuring a centralisation of proceedings, such a rule, unless subject to restrictive conditions, would fuel a 'race to the courtroom', particularly when taken together with the 'first in time' rule governing lis pendens and related actions.

Finally, the proposal to allow consumer associations to bring collective actions in their own domicile, albeit with the important restriction that the entity shall defend only the collective interests of the consumers resident in the forum State, ${ }^{116}$ is inconsistent with the principles laid down by Directive (EU) No 2020/1828 with respect to QEs designated for the purpose of bringing cross-border representative actions: Since Article 2(3) of the Directive explicitly leaves the existing rules on jurisdiction intact and, furthermore, Recital 34 of the Directive provides that QEs, where appropriate, shall provide information on the 'harmful event' constituting the subject-matter of the action in order for the court seised to determine its jurisdiction, the Directive obviously presupposes that consumer associations meeting the requirements of Article 4 of the Directive can bring representative actions in Member States other than the one in which they are established by relying either on the general rule enshrined in Article 4(1) Brussels Ia or, if applicable, on one of the special heads of jurisdiction set out in Title II, Brussels Ia.

In addition, the proposal to limit the 'representation power' of entities to 'nationalise' collective redress proceedings seems guided by overly paternalistic policy objectives. As stated, the Directive provides some protection to consumers not resident in the forum State by means of a mandatory opt-in mechanism (Article 9(3)) and by requiring Member States

115 However, cf Halfmeier and Rott (n 16) 250.

116 Pato (n 2) 231-4, 246-7. 
to ensure that the consumers concerned are provided with information about pending representative actions 'in a timely manner and by appropriate means' (Article 13(2)). In light of these measures, it appears inappropriate to categorically deny consumer associations the right to bring representative actions for redress measures on behalf of both domestic and foreign beneficiaries in any given Member State.

\section{PAVING THE WAY TOWARDS A MORE EFFICIENT USE OF COLLECTIVE REDRESS}

Having identified the shortcomings of the proposals for the introduction of a centralised model of jurisdiction, this section develops an alternative, more refined approach to facilitate the aggregation of similar claims in a single court that, on an ex ante assessment, seems best placed to hear and decide on all claims arising from a given cross-border business practice together. It argues that the objective of promoting cross-border collective redress mechanisms can only be adequately addressed within the framework of a comprehensive overhaul of Brussels Ia, ideally complemented by further supporting legislative measures on the domestic level. The solution proposed here comprises the following four steps.

First, the existing special heads of jurisdiction ought not to be eliminated in relation to collective proceedings but, rather, amended and extended to encompass both individual and collective actions brought against EU defendants as well as non-EU defendants. Second, the threat of pointless parallel mass litigation and forum shopping should be countered by introducing rules that enable a coordinated consolidation of simultaneously pending lawsuits in a single court. Third, if it is truly desired to ensure a swift and smooth resolution of collective disputes to the benefit of consumers, QEs and traders alike (and to relieve the judiciary), it is far from sufficient to reform the jurisdictional system including the rules on lis pendens and related actions. It is also required, inter alia, to facilitate and promote settlements in collective disputes by explicitly addressing the issue of a mutual recognition of in-court and out-of-court settlements, ${ }^{117}$ which, at present, is unfortunately not the case. Finally, to encourage non-profit organisations to initiate proceedings abroad in case of cross-border infringements of EU law, both European and national policymakers should take further action to improve the funding of such entities, eg, by establishing funds composed of leftovers of damages and skimmed off ill-gotten gains paid by traders in accordance with administrative or court decisions, for the purpose of financing such entities. ${ }^{118}$ 


\section{A. Extending the Special Grounds of Jurisdiction to Non-EU Defendants}

Instead of conferring sole and exclusive jurisdiction in collective redress proceedings to the courts of any one Member State, it seems worth considering how the objectively available special fora under Articles 7 and 8 Brussels Ia could be made more accessible for representative bodies to truly promote transnational representative actions. What should be unreservedly welcomed is that the Directive, as stated, requires Member States to ensure that the availability of collective redress is not stymied with regard to the costs associated with the proceedings (Article 20(1)), allows QEs to join forces in a single cross-border representative action (Article 6(2)), and provides for a publicly accessible central electronic database to be set up and maintained by the Commission to facilitate the exchange of information between Member States and QEs (Article 14(3)).

However, if the objective is to introduce a coherent jurisdictional system covering both individual and collective proceedings, the existing dualistic scheme of proceedings brought against EU domiciliaries and actions brought against non-EU domiciliaries cannot be maintained. ${ }^{119}$ Creating a level playing field for all actors participating in the internal market implies that legal action taken against businesses acting in the European market should be subject to unified jurisdictional rules, provided that the required international element of the dispute is established. This is all the more important given that it is all but certain that collective redress proceedings can be initiated against third State defendants with respect to infringements of EU law under the applicable domestic law, even if the damages of the consumers concerned materialised within the EU.

While the prospect of bringing ordinary civil actions against defendants from third States within the Brussels regime might seem rather grim, given that the Commission's proposal to that effect was already rejected in the course of the revision of Brussels I, ${ }^{120}$ that does not alter the fact that harmonisation of the rules regarding EU domiciliaries and non-EU domiciliaries should be further pursued once the revision of Brussels Ia is on the agenda.

\section{B. Empowering the Courts to Coordinate and Consolidate Parallel Proceedings}

The rigidity of the 'first in time principle' entrenched in the rules on lis pendens and related actions ought to be attenuated by implementing a scheme that

\footnotetext{
119 See A Nuyts, 'Study on Residual Jurisdiction: Review of the Member States' Rules concerning the "Residual Jurisdiction" of Their Courts in Civil and Commercial Matters pursuant to the Brussels I and II Regulations' (General Report, European Commission, 3 September 2007) $117-23,155$.

${ }^{120}$ Commission, 'Proposal for a Regulation on jurisdiction and the recognition and enforcement of judgments in civil and commercial matters' COM(2010) 748 final.
} 
furthers cooperation and interaction between courts seised with competing collective actions and allows for a consolidation of proceedings in one of the courts seised to ensure a convenient, just and efficient handling of the pending actions. ${ }^{121}$ Inspiration can be drawn, in particular, from the Federal Rules of Civil Procedure of the United States regarding the coordination and consolidation of multidistrict litigation (28 U.S. Code Section 1407); ${ }^{122}$ from Articles 12 and 13 Brussels IIb Regulation ${ }^{123}$ (previously Article 15 Brussels IIa Regulation), ${ }^{124}$ which allow for a cooperative transfer of jurisdiction in matters relating to parental responsibility; and from Article 6(1) of the Insolvency Regulation, ${ }^{125}$ which extends the jurisdiction of the courts where the main insolvency proceedings are commenced under Article 3 of the Insolvency Regulation to actions 'deriving directly from insolvency proceedings and closely linked with them'. ${ }^{126}$

More specifically, it seems advisable to adopt a rule pursuant to which, when several actions brought against the same defendant or defendants are simultaneously pending before the courts of different Member States, proceedings can be consolidated in one of the courts seised in order to establish common questions of fact and law by way of a cooperative transfer of jurisdiction from the requesting court to the requested court and vice versa within a specified short period of time. The relevant criteria for identifying the forum best placed to determine common elements of the alleged claims are those that have been brought into play for locating the 'centre of gravity' of the collective disputes, eg, the place where the allegedly responsible trader's management and control centre is situated, the place of the most affected market and the place where the majority of the affected individuals reside. ${ }^{127}$

Allowing a concentration of proceedings on the basis of an overall assessment of the circumstances of the case would serve the pursuit of procedural expediency and reduce the risk of inconsistent judgments. Even if applied only exceptionally, the possibility of a subsequent joinder of proceedings in the forum that, according to the shared assessment of the courts seised, is best placed to assess common questions of law and fact

121 See Section III.C.

122 See Hess, 'A Coherent Approach to European Collective Redress' (n 77) 116, para 6.27.

123 Council Regulation (EU) No 2019/1111 of 25 June 2019 on jurisdiction, the recognition and enforcement of decisions in matrimonial matters and the matters of parental responsibility, and on international child abduction [2019] OJ L178/1.

124 Council Regulation (EC) No 2201/2003 of 27 November 2003 concerning jurisdiction and the recognition and enforcement of judgments in matrimonial matters and the matters of parental responsibility, repealing Regulation (EC) No 1347/2000 [2003] OJ L338/1.

125 Regulation (EU) 2015/848 of the European Parliament and of the Council of 20 May 2015 on insolvency proceedings [2015] OJ L141/19.

126 See Stefanelli (n 77) 161, para 9.48; Hess, 'A Coherent Approach to European Collective Redress' (n 77) 117, para 6.28.

127 See Gorywoda, Hatzimihail and Nuyts, 'Introduction: Market Regulation, Judicial Cooperation and Collective Redress' (n 31) 53. 
should counter the threat of a 'race to the courtroom' to a considerable degree. While such a consolidation rule does not completely exclude the possibility of parallel collective litigation, it is arguably more in line with the objective of facilitating the sound administration of justice than the proposal to adopt a necessarily abstract rule of exclusive jurisdiction in collective redress proceedings; furthermore, it dovetails with the general aim of promoting cooperation and mutual trust among the national courts within the whole EU, as has been frequently stressed by the ECJ. ${ }^{128}$

\section{Promoting Settlements in Collective Disputes}

Settlements, be they in-court or out-of-court settlements, are widely considered a vitally important tool for resolving collective disputes in a cost- and time-efficient manner to the benefit of all parties involved. ${ }^{129}$ However, while it is to be welcomed that Article 11 of the Directive lays down, at least partially, the conditions for and effects of judicial approval of settlements within representative action proceedings, this is only a first step towards promoting proper settlements of collective disputes and needs to be accompanied by further supporting measures. In particular, it is of utmost importance to encourage traders to enter into settlements with QEs by explicitly addressing the issue of mutual recognition of in-court and out-of-court settlements. ${ }^{130}$

Given that court-approved settlements do not amount to judgments (within the meaning of Article 2(a) Brussels Ia) ${ }^{131}$ and given that Article 59 Brussels Ia only provides that such settlements are enforceable in Member States other than the Member State of origin under the same conditions as authentic instruments, it is all but certain that settlements approved by the courts of any Member State will be recognised automatically by the courts of any other Member State and thus indeed have preclusive effects (as envisaged by Article 11(4) of the Directive). ${ }^{132}$ At present, there is thus a considerable risk that individual consumers on whose behalf a settlement is entered into and approved by a court might still be able to assert further claims in accordance with the applicable lex causae. ${ }^{133}$ While it is definitely required to increase the parties' confidence in the effectiveness of settlements as a tool for resolving both individual and collective disputes by providing for automatic

\footnotetext{
128 See eg Cases C-159/02 Turner [2004] ECR I-3565, para 24; C-185/07 West Tankers [2009] ECR I-663, para 30.

129 See only Amaro et al. (n 5) 105; but cf Hess, 'A Coherent Approach to European Collective Redress' (n 77) 110, para 6.11.

131 See Briggs (n 45) 754-5, para 33.30.

132 See, in detail, R Fentiman, 'Recognition, Enforcement and Collective Judgments' in A Nuyts and N Hatzimihail (eds), Cross-Border Class Actions: The European Way (Sellier 2014) 102-6; A Stadler, 'Grenzüberschreitende Wirkung von Vergleichen und Urteilen im Musterfeststellungsverfahren' (2020) 73 NJW 265, 268-70.

133 See Stadler (n 132) 269-70.
} 
recognition of court-approved settlements, the EU legislator must also carefully consider how to adapt the existing grounds of non-recognition of judgments, as laid down in Article 45 Brussels Ia, to settlements and judgments arising from collective disputes. ${ }^{134}$

\section{Improving the Funding of QES}

Improving the funding of QEs is crucial for facilitating and promoting the efficient enforcement of EU law through cross-border collective redress, especially in light of the fact that, at present, consumer associations are highly reluctant to take on the costs and risks of initiating proceedings against (corporate) traders abroad. ${ }^{135}$ The need to take further measures at the domestic level to provide adequate financing of consumer associations is all the more pressing given that Member States may designate only non-profit organisations for the purpose of bringing cross-border representative actions (Article 4(3)(c) of the Directive). To meet the requirements of Article 20(1) of the Directive, it seems highly advisable for national legislators to make legal aid readily available for QEs and, furthermore, to improve financing of consumer associations by establishing funds that, as stated above, might be composed of settlement leftovers and other monies paid by traders in accordance with administrative or judicial decisions arising from collective actions. $^{136}$

\section{E. Merits of the Proposal}

Overall, the comprehensive approach outlined above markedly differs from proposals submitted by other scholars, as it specifically argues in favour of maintaining and extending the special grounds of jurisdiction to domiciliaries from third States in both individual and collective disputes. While this proposal is likely to meet some opposition, there is no denying that the alternative suggestion to adopt a centralised model of jurisdiction for collective redress is apt to upset the very balance that the existing jurisdictional system seeks to achieve between the parties to the dispute. ${ }^{137}$ In contrast, the solution proposed here adequately responds to the competing policy objectives that need to be taken into account when considering how to adapt Brussels Ia to the needs of collective redress. ${ }^{138}$

First, it strikes a reasonable balance between traders and entities. It neither generally precludes QEs from ever relying on the special heads of jurisdiction (with the exception of those specifically designed to protect the

134 See Amaro et al. (n 5) 104-5, correctly noting that art 45 Brussels Ia does not provide sufficient protection to the individuals involved in collective disputes in cases where the action is based on an opt-out scheme.

135 See Biard and Kramer (n 3) 256-7.

136 See art 9(7) of the Directive, according to which the allocation of outstanding redress funds may be regulated by national law.

137 See Section IV.

138 See Section I. 
vulnerable party such as Article 18(1) Brussels Ia), ${ }^{139}$ nor does it allow entities to always comfortably initiate proceedings on their home turf or in the fictitious 'centre of the collective interests' of the represented consumers, which, most likely, coincides with the place where the entity is established. Rather, it generally ensures that the allegedly responsible trader may only be sued in the courts of a Member State other than the one in which it is domiciled if the courts of that other State are competent to hear and decide on each claim according to the special grounds of jurisdiction.

Second, by maintaining that jurisdiction be established independently and separately for each consumer concerned and each claim, this approach is consistent with the principle on which all exceptions from the general rule of Article 4(1) Brussels Ia are said to be based, that is, the supposed existence of a 'particularly close connection' between the dispute and the competent court. ${ }^{140}$ As stated, it generally guarantees that the objective of proximity is met with respect to each individual claim, thereby avoiding the spillover effects inherent in the opposing proposal to construct a fictitious 'centre of the affected group's main interests' on the basis of vaguely defined abstract criteria that are at best approximations for identifying the required close link between all the aggregated claims of the consumers concerned and the competent forum.

Third, this proposal nevertheless responds to the aim of ensuring a cost- and time-efficient resolution of collective disputes by empowering the courts seised of competing actions to subsequently consolidate proceedings in the court that seems best placed to determine common questions of law and fact. It therefore substantially reduces the threat of inconsistent judgments, while the possibility of a subsequent consolidation of the parallel proceedings in a court other than the one first seised counters the threat of uncontrolled forum shopping. In sum, the proposal is thus well in accordance with the (opaque) principle of the sound administration of justice. ${ }^{141}$

Fourth, by maintaining the established special grounds of jurisdiction for individual and collective disputes, this solution is also consistent with the overriding aim of ensuring legal certainty and predictability of jurisdiction. That conclusion is not called into question by the mere possibility of a subsequent concentration of parallel proceedings in a single court on the basis of an overall assessment of the circumstances of the case. Given that the solution suggested here only provides for a subsequent consolidation of parallel proceedings in a court that is otherwise competent to determine at least one of the competing actions according to the existing jurisdictional rules, jurisdiction is sufficiently predictable for all parties involved. In particular, any trader 'targeting' consumers in several Member States within

\footnotetext{
139 See Section II.B.

140 See only Zuid-Chemie (n 100) para 24. 4.05 .

As to which, see Lein, 'Special Jurisdiction for Particular Kinds of Claims' (n 20) 133, para
} 
the EU must envisage the possibility of a subsequent consolidation of competing actions initiated in any one of those States.

Finally, apart from the fact that this proposal is well in line with the principles underlying the jurisdictional system, it also furthers the policy objectives of Directive (EU) No 2020/1828: Extending the special grounds of jurisdiction to non-EU defendants for representative actions lays the necessary foundation for efficient enforcement of EU law vis-à-vis all traders in the internal market and thus contributes to establishing a level playing field in the EU, as envisaged in Recital 7 of the Directive.

\section{CONCLUSION}

While the entry into force of Directive (EU) No 2020/1828 could stimulate, support and facilitate the gradual emergence of a common European collective litigation culture, the need to take further legislative action to adequately accommodate collective redress within the Brussels regime is obvious. The tendency of the existing jurisdictional system to promote inefficient parallel proceedings arising from cross-border infringements of EU consumer law and mass torts can be only slightly countered by a more refined verification of the 'relevant activity' and the ensuing 'initial damage' in some particular mass harm situations under the two limbs of the Bier rule based on Article 7(2) Brussels Ia. Moreover, the existing rules on lis pendens and related actions, even if reinterpreted as submitted in this article, are simply not designed to ensure that, in cases of competing and/or overlapping mass proceedings, common questions of law and fact can be determined by a court that, in light of the particular circumstances of the case, seems best placed to do just that.

Against this background, this article critically assesses some of the most recent academic proposals for amending the existing European private international law regime to better cope with collective redress and identifies a possible way forward. In contrast to many other scholars, it strongly rejects the proposal to introduce a 'one-stop-shop jurisdiction' for collective redress, be it by conferring exclusive jurisdiction to the courts of the defendant's domicile or by constructing a 'centre of the group's main interests'. Instead of centralising judicial competence for collective redress by introducing a novel head of jurisdiction that unduly favours either entities or traders to the detriment of the other party to the dispute, the policy of fostering consumers' access to justice through collective redress should and, indeed, could be achieved in a way that better complies with the principles on which the jurisdictional framework is based. To this end, this article proposes (i) to maintain and extend the special grounds of jurisdiction to non-EU defendants both in individual and collective disputes, (ii) to supplement the rules on lis pendens and related actions by a rule that provides for a cooperative consolidation of 
competing mass proceedings on a case-by-case basis, and (iii) to specifically regulate mutual recognition of court-approved settlements.

The solution proposed here has considerable merits. It strikes a reasonable balance between QEs and traders; contributes to the pursuit of procedural expediency by allowing a court-ordered consolidation of parallel (mass) proceedings on a case-by-case basis; counters the threat of a 'race to the courtroom' by allowing the courts, of their own motion, to consolidate competing actions in the court best placed to determine all claims together; and provides for equal treatment, at the level of jurisdiction, of all market participants, regardless of whether they are established within the EU or in a third State.

While there is still much to be done, both at the EU level and at the domestic level, to fully unleash the potential of cross-border collective redress as a viable tool of private enforcement of EU law, the new Representative Actions Directive marks a first necessary step towards improving consumers' access to justice and at the same time adequately responds to widespread fears about abusive mass litigation. It can only be hoped that the policy of promoting and facilitating collective redress will soon be backed up by a thorough and wellbalanced reform of Brussels Ia, ideally taking up some of the measures proposed in this article. 